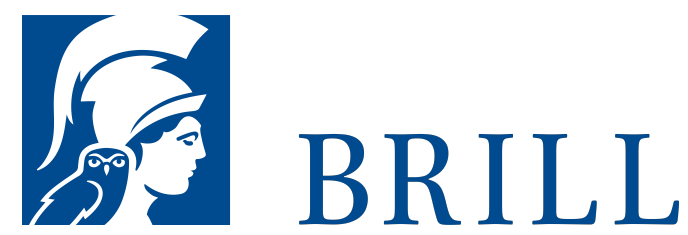

\title{
Audias fabulas veteres. Anatolian Studies in Honor of Jana Součková- Siegelová
}

\section{Editor: Šárka Velhartická}

The publication Audias fabulas veteres. Anatolian Studies in Honor of Jana Součková-Siegelová contains 31 contributions on current research topics in the fields of Ancient Anatolian and Near Eastern Languages, History, Religion, and Literature. The topics cover not only the main languages of this geographical area, such as Hittite, Luwian, Hattian, Hurrian, Akkadian, and Sumerian but also comparative linguistics and the latest methods of digitalising cuneiform texts, as well as religion, mythology and divinities, rituals, proverbs and analysis of geographical and historical documentation. Finally, it offers new analyses of some of the most remarkable texts and text passages of the ancient Anatolian literary tradition.

\section{Readership}

All interested in Ancient Anatolian Studies, especially the languages of Ancient Anatolia and the Near East, and anyone concerned with Comparative Linguistics, Near Eastern Studies, Ancient Religion, Literature and History.

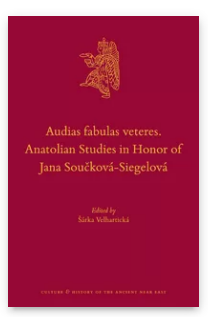

Language:

English

Subjects:

Linguistics,

Ancient Near

East and Egypt,

History, Ancient

Near East and

Egypt

Publisher: Brill

Series:

Culture and History of the Ancient Near East, Volume: 79

E-Book (PDF)

Released online: 29 Aug 2016

ISBN: 978-90о4-31261-6

List price

USD \$235.00

Hardback Publication date: o8 Sep 2016

ISBN: 978-9004-3126o-9 List price USD $\$ 235.00$ 
Mgr. Šárka Velhartická,Ph.D. (2011), studied Languages and Archaeology of the Ancient Near East at the Freie Universität Berlin, and Cuneiform, Ethnology and Comparative Linguistics at Charles University in Prague. She specialises in ancient Anatolia, comparative linguistics and multilingual education, and is editor of the volumes Bedrich Hrozný and 100 Years of Hittitology and Dopisy Bedřicha Hrozného literárním osobnostem.

For more information see brill.com

Order information: Order online at brill.com +44330 3330049 | customerservices@brill.com Submission information: brill.com/authors

Titles published by Brill | Fink, Brill | mentis or Brill | Schöningh: +49(o)71 5413279216 | brill@brocom.de 